\title{
Faktor yang Mempengaruhi Penyelesaian Tugas Akhir Mahasiswa Teknik Industri Sekolah Tinggi Teknologi Dumai
}

\author{
Wetri Febrina ${ }^{1}$, Muhammad Arif ${ }^{2}$, Andriansyah ${ }^{3}$ \\ 1,2,3)Program Studi Teknik Industri, Sekolah Tinggi Teknologi Dumai \\ Jl. Utama Karya Bukit Batrem II \\ Email: wetri.febrina@gmail.com
}

\begin{abstract}
ABSTRAK
Penelitian ini bertujuan untuk mengetahui pengaruh motivasi, kemampuan menulis tugas akhir, lingkungan teman kampus, dan ketersediaan sumber belajar secara bersama-sama terhadap penyelesaian tugas akhir mahasiswa teknik indsutri angkatan 2014. Populasi penelitian ini adalah mahasiswa Teknik Industri STT Dumai angkatan 2014 dengan metode penarikan sampel purpossive sampling sebanyak 50 orang. Pengumpulan data menggunakan kuesioner. Teknik analisis data yang digunakan adalah teknik analisis regresi linier berganda untuk mengetahui pengaruh variabel-variabel bebas (motivasi, kemampuan menulis tugas akhir, lingkungan teman kampus, ketersediaan sumber belajar) terhadap variabel terikat (penyelesaian tugas akhir) dengan pengujian hipotesis uji $\mathrm{F}$ dan uji T.Hasil penelitian ini menunjukkan, variabel-variabel bebas (motivasi, kemapuan menulis tugas akhir, lingkungan teman kampus, ketersediaan sumber belajar) secara bersama-sama berpengaruh terhadap variabel terikat (penyelesaian tugas akhir) dengan ditunjukkan nilai nilai Fhitung $(4,304)$ lebih besar dari Ftabel $(2,58)$ dan nilai R2 sebesar 0,277 atau 27,7\% artinya variabel-variabel bebas (motivasi, kemampuan menulis tugas akhir, lingkungan teman kampus, dan ketersediaan sumber belajar) berpengaruh terhadap variabel terikat (penyelesaian tugas akhir), dan sisanya $72,7 \%$ dipengaruhi oleh variabel lainnya, dan untuk variabel yang paling berpengaruh yaitu ketersediaan sumber belajar.
\end{abstract}

Kata kunci: Tugas Akhir, Mahasiswa Teknik Industri, motivasi, kemampuan menulis.

\begin{abstract}
This study aims to determine the effect of motivation, the ability to write the final assignment, the campus community environment, and the availability of learning resources together on the completion of the final project of the 2014 industrial engineering students. The population of this research was Sekolah Tinggi Teknologi Dumai Industrial Engineering students class of 2014 with a sampling method of purposive sampling as many as 50 people. Data collection using a questionnaire. Data analysis techniques are multiple linear regression techniques to determine the effect of independent variables (motivation, writing ability, learning environment, availability of learning) to dependent variables (the completion of the final project) by hypothesis testing the $F$ test and T-test. The results of this study indicate that the independent variables (motivation, ability to write the final plan, learning environment, learning
\end{abstract}


information) together to measure the value (Fcount (4.304) is greater than Ftable (2.58) and R2 values are 0.277 or $27.7 \%$ means independent variables(motivation, writing ability of the final project, environment campus friends, and availability of learning), and other variables influence the remaining $72.7 \%$, and for the most influential variables are the availability of learning resources.

Keywords: Thesis, Student of Industrial Engineering, Motivation, Writing Skill

\section{Pendahuluan}

Mahasiswa merupakan tahapan pendidikan yang menuntut untuk bisa bertindak dan menghasilkan karya. Mahasiswa berkewajiban untuk meningkatkan mutu diri dan mutu bangsa dengan mempelajari suatu bidang ilmu selama menempuh pendidikan di kampus kemudian ilmu yang telah mereka kuasai melalui proses pendidikan di perguruan tinggi harus diimplementasikan dan diterapkan. Tidak hanya dituntut memiliki pengetahuan dan keterampilan, namun juga memiliki sikap peduli terhadap lingkungan masyarakat. Sebelum mereka melakukan pengabdian masyarakat dan menerapkan ilmu mereka kepada masyarakat, mereka terlebih dahulu dituntun untuk bisa mandiri dan memiliki tanggung jawab untuk menyelesaikan tugas-tugas akademiknya. Tugas-tugas akademik tersebut antara lain, penyelesaian tugas kuliah, praktikum, penyelesaian tugas di lapangan, dan penyelesaian tugas akhir atau skripsi. Tugas Akhir atau skripsi merupakan karya tulis ilmiah yang harus diselesaikan secara mandiri oleh mahasiswa. Menyelesaikan skripsi harus ditempuh oleh semua mahasiswa S1 yang ingin mendapatkan gelar sarjana. Tentu saja dalam proses mengerjakan skripsi, bukan suatu hal yang mudah, banyak kendala yang dihadapi dan tentu harus ada pengorbanan yang dilalui dalam mengerjakannya. Mengerjakan skripsi membutuhkan proses panjang dan juga tenaga, biaya, waktu, dan perhatian yang tidak sedikit.

Data awal berdasarkan hasil wawancara menemukan banyaknya hambatan dalam mengerjakan skripsi tentu membuat mahasiswa yang tidak lulus tepat waktu dan memberi dampak negatif bagi pihak perguruan tinggi juga bagi mahasiswa itu sendiri. Beberapa faktor yang mempengaruhi terlambatnya mahasiswa tersebut dalam mengerjakan skripsi yang sudah pernah diteliti sebelumnya seperti, kurangnya sks yang diambil, belum menemukan judul yang sesuai, kurangnya motivasi, rasa malas, lingkungan yang kurang mendukung baik fisik maupun sosial seperti teman, tidak cocok dengan dosen pembimbing, sulitnya menemui dosen pembimbing, sulitnya menemukan sumber teori yang dibutuhkan, kurangnya kemampuan mengelola kata saat menulis, ketidakpahaman mengenai karya tulis ilmiah, dan kesibukan mahasiswa itu sendiri seperti kerja, dan sebagainya (Alafgani, 2013; Aslinawati dan Minarti, 2017, ;.Hartanto, 2016). Hal tersebut melatarbelakangi penulis melakukan penelitian untuk mengetahui faktor-faktor yang mempengaruhi penyelesaian tugas akhir mahasiswa S1 Teknik Industri di Sekolah Tinggi Teknologi Dumai. 


\section{Metode Penelitian}

Subjek penelitian ini adalah mahasiswa S1 Teknik Industri di Sekolah Tinggi Teknologi Dumai yang sedang mengambil dan melakukan penelitian Tugas Akhir selama tahun ajaran 2018/2019. Populasi pada penelitian ini berjumlah 125 orang. Penulis menggunakan metode non probability sampling, yaitu setiap elemen dari populasi tidak memiliki kesempatan yang sama untuk ditarik menjadi sampel, dan dengan menggunakan metode purposive sampling diputuskan jumlah sample yang mewakili populasi adalah sebanyak 50 sampel (Sinulingga, 2013).

Pengambilan data dilakukan dengan melakukan penyebaran kuesioner Pertanyaan kuesioner dibagi menjadi 4 variabel, yaitu motivasi, kemampuan menulis, lingkungan teman kampus dan ketersediaan sumber mengajar. Pertanyaan untuk setiap variable disusun secara tertutup sebanyak total 45 pertanyaan. Untuk mengukur nilai masing-masing variable, penulis menggunakan skala Likert dengan skala 1-4.

\section{Hasil dan Pembahasan}

\section{Uji Statistik Dasar dan Uji Asumsi Klasik}

Uji statistik dasar atau uji deskriptif statistik dilakukan untuk melihat sifat dari data, berupa rata-rata, median, modus, distribusi frekuensi dan standar deviasi. Uji asumsi klasik yang dilakukan meliputi uji normalitas, uji multikoliniearitas, uji heterokedastisitas dan uji hipotesis. Setiap hasil yang ditampilkan baik dalam bentuk grafik, kurva, atau tabel harus ada uraian analisa dan pembahasannya. Jangan sampai pembaca justru tidak dapat memahami hasil tersebut karena minimnya analisa atau penjelasan yang dikemukakan oleh penulis.

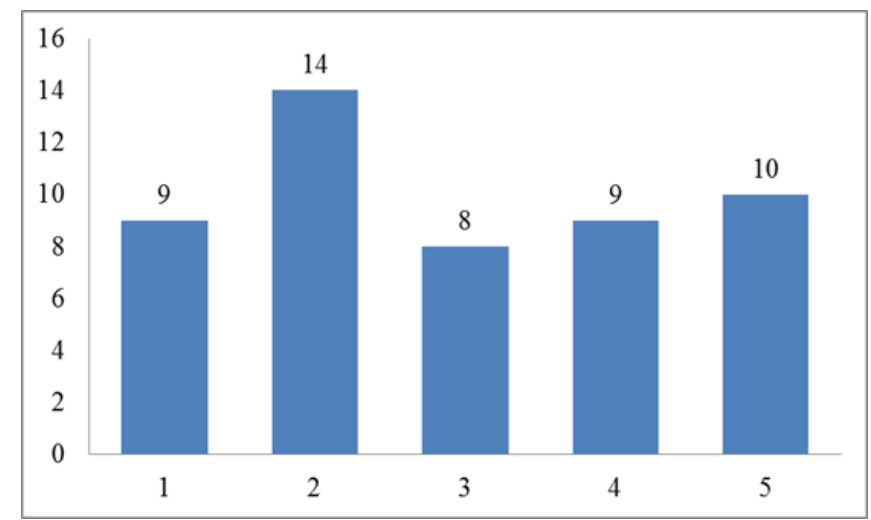

Gambar 1. Histogram Distribusi Frekuensi Penyelesaian Tugas Akhir Mahasiswa Teknik Industri STT Dumai 2018 


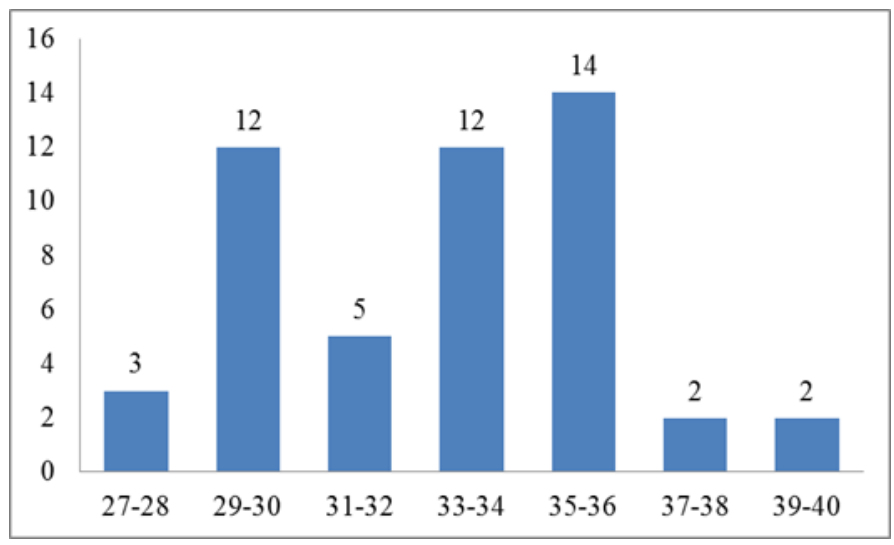

Gambar 2. Histogram distribusi frekuensi variabel motivasi

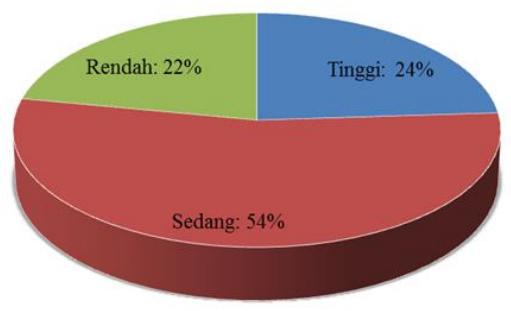

Gambar 3. Pie chart distribusi frekuensi variabel kemampuan menulis

Tabel 1. Hasil output uji normalitas

One-Sample Kolmogorov-Smirnov Test

\begin{tabular}{|ll|r|}
\hline & & $\begin{array}{c}\text { Unstandardized } \\
\text { Residual }\end{array}$ \\
\hline$N$ & Mean & 50 \\
Normal Parameters & & .0000000 \\
Most Extreme Differences & Std. Deviation & 1.20777023 \\
& Absolute & .090 \\
& Positive & .090 \\
Kolmogorov-Smirnov $Z$ & Negative & -.076 \\
Asymp. Sig. (2-tailed) & & .687 \\
\hline
\end{tabular}

a. Test distribution is Normal.

Berdasarkan Tabel 1, hasil output uji normalitas diatas menggunakan uji onesample Kolmogorov-Smirnov, diketahui bahwa nilai signifikan 0,812 atau lebih besar dari 0,05 maka dapat disimpulkan bahwa populasi data berdistribusi normal. 
Tabel 2. Hasil output uji multikolinearitas

\begin{tabular}{|c|c|c|c|c|c|c|c|c|}
\hline \multicolumn{9}{|c|}{ Coefficients $^{a}$} \\
\hline \multirow{2}{*}{ Model } & & \multicolumn{2}{|c|}{$\begin{array}{c}\text { Unstandardized } \\
\text { Coefficients }\end{array}$} & \multirow{2}{*}{\begin{tabular}{|c|}
$\begin{array}{c}\text { Standardized } \\
\text { Coefficients }\end{array}$ \\
Beta \\
\end{tabular}} & \multirow{2}{*}{$t$} & \multirow{2}{*}{ Sig. } & \multicolumn{2}{|c|}{$\begin{array}{l}\text { Collinearity } \\
\text { Statistics }\end{array}$} \\
\hline & & $B$ & $\begin{array}{l}\text { Std. } \\
\text { Error }\end{array}$ & & & & $\begin{array}{c}\text { Tolera } \\
\text { nce }\end{array}$ & $V I F$ \\
\hline \multirow[t]{5}{*}{1} & (Constant) & -4.2 & 2.505 & & -1.676 & 0.101 & & \\
\hline & $\begin{array}{l}\text { Motivasi } \\
\text { Kemampuan }\end{array}$ & 0.077 & 0.069 & 0.162 & 1.113 & 0.272 & 0.755 & 1.324 \\
\hline & $\begin{array}{l}\text { Menulis Tugas } \\
\text { Akhir }\end{array}$ & 0.125 & 0.06 & 0.328 & 2.064 & 0.045 & 0.638 & 1.568 \\
\hline & $\begin{array}{l}\text { Lingkungan } \\
\text { Teman Kampus }\end{array}$ & -0.123 & 0.064 & -0.335 & -1.919 & 0.061 & 0.526 & 1.901 \\
\hline & $\begin{array}{l}\text { Ketersediaan } \\
\text { Sumber Belajar }\end{array}$ & 0.176 & 0.077 & 0.38 & 2.288 & 0.027 & 0.583 & 1.716 \\
\hline
\end{tabular}

Berdasarkan Tabel 2 hasil output Coefficients dapat dilihat kolom VIF diketahui bahwa nilai VIF untuk variable bebas berada di bawah 10. Karena nilai VIF kurang dari 10, maka dapat disimpulkan bahwa pada model regresi tidak ditemukan adanya masalah multikolinearitas.

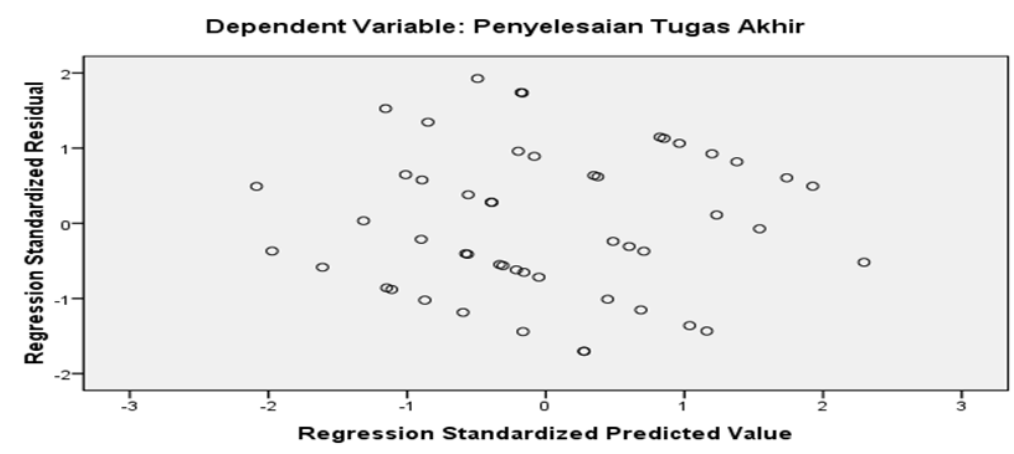

Gambar 4. Hasil output uji heteroskedastisitas menggunakan grafik regresi

Dari Gambar 4 terlihat bahwa sebaran titik tidak membentuk suatu pola/alur tertentu, sehingga dapat disimpulkan tidak terjadi heteroskedastisitas atau dengan kata lain terjadi homoskedastisitas. Asumsi klasik tentang heteroskedastisitas dalam model ini terpenuhi, yaitu terbebas dari heteroskedastisitas.

Tabel 3. Hasil uji regresi berganda

\begin{tabular}{|l|r|r|r|r|r|}
\hline Model & $R$ & $R$ Square & $\begin{array}{c}\text { Adjusted } R \\
\text { Square }\end{array}$ & $\begin{array}{c}\text { Std. Error of } \\
\text { the Estimate }\end{array}$ & $\begin{array}{c}\text { Durbin- } \\
\text { Watson }\end{array}$ \\
\hline 1 & $.526^{\mathrm{a}}$ & 0.277 & 0.212 & 1.26031 & 1.177 \\
\hline
\end{tabular}
a. Predictors: (Constant), Ketersediaan Sumber Belajar, Motivasi, Kemampuan
Menulis Tugas Akhir, Lingkungan Teman Kampus
b. Dependent Variable: Penyelesaian Tugas Akhir




\begin{tabular}{|c|c|c|c|c|c|c|c|c|}
\hline \multirow{2}{*}{\multicolumn{2}{|c|}{ Variabel }} & \multicolumn{2}{|c|}{ Harga $\mathrm{R}$ dan $R$ Square } & \multicolumn{2}{|c|}{ Harga $F$} & \multirow{2}{*}{ Koef. } & \multirow{2}{*}{ Konst. } & \multirow{2}{*}{ Keterangan } \\
\hline & & $\mathrm{R}$ & R Square & Hitung & Tabel & & & \\
\hline $\mathrm{X} 1$ & \multirow{4}{*}{$\mathrm{Y}$} & \multirow{4}{*}{0,526} & \multirow{4}{*}{0,277} & \multirow{4}{*}{4,304} & \multirow{4}{*}{2,58} & 0,077 & \multirow{4}{*}{$-4,2$} & Positif \\
\hline $\mathrm{X} 2$ & & & & & & 0,125 & & Positif \\
\hline $\mathrm{X} 3$ & & & & & & $-0,123$ & & Negatif \\
\hline $\mathrm{X} 4$ & & & & & & 0,176 & & Positif \\
\hline
\end{tabular}

Tabel 4. Hasil analisis regresi linier berganda

Berdasarkan Tabel 4, maka persamaan regresi dapat dinyatakan sebagai berikut:

$$
\mathrm{Y}=0,077 \mathrm{X} 1+0,125 \mathrm{X} 2-0,123 \mathrm{X} 3+0,176 \mathrm{X} 4-4,2
$$

Persamaan tersebut menunjukkan bahwa jika:

1. Nilai Motivasi (X1) naik 1 poin dan diasumsikan nilai variabel lain (X2,X3,X4) tetap, maka nilai Penyelesaian Tugas Akhir (Y) akan meningkat 0,077 poin.

2. Nilai Kemampuan Menulis Tugas Akhir (X2) naik 1 poin dan diasumsikan nilai variabel lain $(\mathrm{X} 1, \mathrm{X} 3, \mathrm{X} 4)$ tetap, maka nilai Penyelesaian Tugas Akhir (Y) akan meningkat 0,125 poin.

3. Nilai Lingkungan Teman Kampus (X3) naik 1 poin dan diasumsikan nilai variabel lain $(\mathrm{X} 1, \mathrm{X} 2, \mathrm{X} 4)$ tetap, maka nilai Penyelesaian Tugas Akhir (Y) akan turun 0,123 poin.

4. Nilai Ketersediaan Sumber Belajar (X4) naik 1 poin dan diasumsikan nilai variabel lain $(\mathrm{X} 2, \mathrm{X} 3, \mathrm{X} 4)$ tetap, maka nilai Penyelesaian Tugas Akhir (Y) akan meningkat 0,176 poin.

Dari penjelasan diatas dapat disimpulkan bahwa terdapat pengaruh positif variabel motivasi, kemampuan menulis tugas akhir, dan ketersediaan lingkungan teman kampus, dan terdapat pengaruh negatif variabel lingkungan teman kampus secara bersama sama terhadap penyelesaian tugas akhir.

\section{Simpulan}

Berdasarkan hasil analisis dan evaluasi yang telah dilakukan, maka dapat ditarik kesimpulan yaitu pengaruh motivasi, kemampuan menulis, lingkungan teman kampus dan ketersediaan sumber belajar bersama-sama terhadap penyelesaian tugas akhir diketahui bahwa $\mathrm{F}$ hitung $>$ dari $\mathrm{F}$ table $(4,304>2,58)$. Dan didapat persamaan regresi $\mathrm{Y}=0,077 \mathrm{X} 1+0,125 \mathrm{X} 2-0,123 \mathrm{X} 3+0,176 \mathrm{X} 4-4,2$ dengan kesimpulan bahwa terdapat pengaruh positif variabel motivasi, kemampuan menulis tugas akhir, dan ketersediaan sumber belajar, dan terdapat pengaruh negatif variabel lingkungan teman kampus secara bersama-sama terhadap penyelesaian tugas akhir. Hasil uji t tiap variabel independen terhadap variabel dependen dapat diketahui bahwa faktor yang berpengaruh terhadap penyelesaian tugas akhir adalah variabel ketersediaan sumber belajar. 


\section{Daftar Pustaka}

Alafgani, A. P. (2013). Faktor-Faktor Kesulitan dalam Menyelesaikan Mata Kuliah. Skripsi tidak diterbitkan. Universitas Pendidikan Indonesia, Bandung.

Arikunto, S. (2010). Prosedur Penelitian Suatu Pendekatan Praktik. Jakarta: PT Rineka Cipta.

Aslinawati, N.E. \& Minarti, S.U. (2017). Keterlambatan Penyelesaian Skripsi Mahasiswa Angkatan 2012 (Studi Kasus Di Jurusan Ekonomi Pembangunan Fakultas Ekonomi Universitas Negeri Malang). Jurnal Pendidikan Ekonomi, 10 (1).

Asmawan, M.C. (2016). Analisis Kesulitan Mahasiswa Menyelesaikan Skripsi. Jurnal Pendidikan Ilmu Sosial, 26(2).

Dalman. (2014). Menulis Karya Ilmiah. Jakarta: PT Raja Grafindo Persada.

Faelasofi, R. (2018). Faktor Dominan Kesulitan Mahasiswa Pada Penulisan Skripsi. Jurnal Edumath , 4(1), 95-107.

Ghozali, I. (2007). Aplikasi Analisis Multivariate Dengan Program SPSS. Semarang: Badan Penerbit Universitas Diponegoro.

Hamalik, O. (2004). Psikologi Belajar dan Mengajar. Bandung: Sinar Baru Algensindo.

Hartanto, U. (2016). Faktor - Faktor Yang Mempengaruhi Penyelesaian Tugas Akhir Skripsi (Tas) Mahasiswa Program Studi Pendidikan Kuntansi Fakultas Ekonomi Universitas Negeri Yogyakarta Angkatan 2011. Skripsi tidak diterbitkan. Fakultas Ekonomi, Universitas Negri Yogyakarta, Yogyakarta.

Irham, M. \& Wiyani, N.A. (2014). Psikologi Pendidikan. Yogyakarta: Ar-Ruzz Media.

Kusnedar, F. (2012). Analisis Penghambat Penyelesaian Studi Mahasiswa S1 Program Studi Pendidikan Teknik Mesin Jurusan Pendidikan Teknik dan Kejuruan Fakultas Keguruan dan Ilmu Pendidikan Universitas Sebelas Maret Surakarta. Skripsi tidak diterbitkan, Fakultas Keguruan dan Ilmu Pendidikan, Universitas Sebelas Maret, Surakarta.

Mulyasa. (2011). Menjadi Guru Profesional (Menciptakan Pembelajaran Kreatif dan Menyenangkan). Bandung: PT Remaja Rosdakarya.

Perdana, E. (2016). Olah Data Skripsi Dengan SPSS 22. Bangka Belitung: Lab Kom Manajemen FE UBB. 
Purwanto, N.M. (2007). Psikologi Pendidikan. Bandung: PT Remaja Rosdakarya

Rusmawati, K.R., Tripalupi, L.E., \& Artana, M. (2014). Faktor-Faktor Yang Mempengaruhi Terhambatnya Penyelesaian Studi Mahasiswa Jurusan Pendidikan Ekonomi Tahun 2012/2013. Jurnal Pendidikan Ekonomi, 4(1).

Sardiman, A.M. (2009). Interaksi dan Motivasi Belajar Mengajar. Jakarta: PT Raja Grafindo Persada.

Sinulingga, S. (2013). Metode Penelitian (Edisi 3). Medan: Usu Press.

Siswanto, I., \& Sampurno, Y.G. (2013). Faktor-Faktor Penghambat Penyelesaian Tugas Akhir Skripsi Mahasiswa Pendidikan Teknik Otomotif FT UNY. E-Joernal. Yogyakarta: FT UNY.

Siti Maslakhah, dkk. (2011). Bahasa Indonesia: Panduan Menulis Karya Ilmiah. Yogyakarta: Kanwa Publisher.

Sudarya, I.W., Bagia, I.W., \& Suwendra, I.W. (2014). Analisis Faktor-Faktor Yang Mempengaruhi Stres Pada Mahasiswa Dalam Penyusunan Skripsi Jurusan Manajemen Undiksha Angkatan 2009. e-Journal Bisma Universitas Pendidikan Ganesha Jurusan Manajemen, 2(1).

Sugiyono. (2007). Stastistika untuk Penelitian. Bandung: Alfabeta.

Sukmadinata, N.S. (2009). Landasan Psikologis Proses Pendidikan. Bandung: PT Remaja Rosdakarya.

Zaman, B. (2006). Pengelolaan dan Pemanfaatan Sumber Belajar di Taman KanakKanak. Makalah. Banten: LPPM. 